\title{
Quantification of Selected Vapour-Phase Compounds using Thermal Desorption-Gas Chromatography*
}

\author{
by \\ D.W.J. McLaughlin, R.E. Bell, D.J. Graham, and R. McKeivor \\ Gallaher Ltd, Galgorm Road, Ballymena, Co. Antrim, BT42 1HS, N. Ireland
}

\section{SUMMARY}

A robust method for the analysis of selected vapour phase (VP) compounds in mainstream smoke (MSS) is described. Cigarettes are smoked on a rotary smoking machine and the VP that passes through the Cambridge filter pad collected in a Tedlar ${ }^{\circledR}$ bag. On completion of smoking, the bag contents are sampled onto an adsorption tube containing a mixed carbon bed. The tube is subsequently analysed on an automated thermal desorption (TD) system coupled to a gas chromatography-flame ionization detector (GC-FID) using a PoraPLOT-Q column. Quantification of 14 volatile compounds including the major carbonyls is achieved. Details of the method validation data are included in this paper. This method has been used to analyse the VP of cigarette MSS over a wide range of 'tar' deliveries and configurations with excellent repeatability. Results for the University of Kentucky reference cigarette $1 \mathrm{R} 4 \mathrm{~F}$ are in good agreement with reported values. [Beitr. Tabakforsch. Int. 21 (2004) 210-215]

\section{ZUSAMMENFASSUNG}

Es wird eine robuste Methode zur Analyse ausgewählter Verbindungen in der Gasphase des Hauptstromrauchs von Zigaretten beschrieben. Die Zigaretten wurden mit einer Rotations-Rauchmaschine abgeraucht und die Gasphase, die den Cambridgefilter passiert, wurde in einem Tedlar®Beutel gesammelt. Nach Beendigung des Abrauchens erfolgte eine Probenentnahme aus dem Beutel auf ein Adsorptionsröhrchen mit einem gemischten Kohlebett. Das Röhrchen wurde dann mit einem automatisierten thermischen Desorptionssystem, gekoppelt mit einem Gaschromatographen und Flammenionisationsdetektor (GC-FID), unter Verwendung einer PoraPLOT-Q-Säule analysiert. Es erfolgte die Quantifizierung von 14 volatilen Verbindungen, einschließlich der wichtigsten Carbonylverbindungen. Es werden detaillierte Daten zur Validierung der Methode mitgeteilt. Die Methode wurde dazu eingesetzt, um die Gasphase des Hauptstromrauchs von Zigaretten mit unterschiedlichen Kondensatgehalten und Produkteigenschaften zu analysieren. Die Wiederholbarkeit der Methode ist sehr gut. Die erzielten Resultate für die Referenzzigarette 1R4F der University of Kentucky sind in guter Übereinstimmung mit publizierten Werten. [Beitr. Tabakforsch. Int. 21 (2004) 210-215]

\section{RESUME}

Une méthode robuste pour analyser certains composés de la phase gazeuse de la fumée du courant principal est présentée. Les cigarettes ont été fumées sur une machine à fumer rotative, et la phase gazeuse passée à travers le filtre Cambridge a été recueillie dans des sacs d'échantillonnage Tedlar®. Après fumage, les échantillons ont été injectés sur un tube d'adsorption contenant une couche de charbon mélangée. Ensuite le tube a été analysé sur un système de désorption thermique automatisée couplé à un dispositif de chromatographie en phase gazeuse-détection par ionization de flamme (GC-FID) à l'aide d'une colonne PoraPLOT-Q. Le dosage de 14 composés volatils y compris les carbonyles principaux a été réalisé. Dans cette étude des données détaillées de validation de la méthode sont présentées. Cette méthode a été employée pour analyser la phase gazeuse de la fumée principale de cigarettes d'un large éventail de rendements en goudron et différenciations des produits et ceci avec une répétabilité excellente. Les résultats obtenus avec la cigarette de référence Kentucky 1R4F sont en bon accord avec les valeurs rapportées. [Beitr. Tabakforsch. Int. 21 (2004) 210-215] 
Table 1. Amount of compounds in $1 \mu \mathrm{L}$ of standard

\begin{tabular}{l|c}
\hline Compound & Amount $(\mu \mathrm{g})$ \\
\hline Acetaldehyde (Acetal) & 2772 \\
Acetonitrile & 1187 \\
Acetone (Aceton) & 262 \\
Acrolein (Acrol) & 210 \\
Acrylonitrile & 81 \\
Benzene & 87 \\
2-Butanone (MEK) & 268 \\
Butyraldehyde (Butal) & 267 \\
Crotonaldehyde (Crotal) & 85 \\
Furan & 94 \\
Isoprene & 1362 \\
Methanol & 791 \\
Propionaldehyde (Propal) & 201 \\
Toluene & 87 \\
\hline
\end{tabular}

\section{INTRODUCTION}

High-temperature pyrolysis of tobacco at the burning cone produces a vapour containing volatile compounds, many of which are not present in tobacco (1). The heat of combustion also vapourises many compounds from the tobacco near the burning cone. Whilst many of these compounds condense, some pass through the tobacco rod and filter into the mainstream smoke (MSS) (1). The Cambridge filter pad fractionates the MSS into the particulate phase (having a nominal size greater than 0.3 microns) and the vapour phase (VP) (2). Many of the VP components are of biological interest, e.g. benzene is a known human carcinogen (3). Consequently, several of these chemicals have come under scrutiny by regulators, e.g. in British Columbia and Massachusetts. Additionally many volatile compounds are believed to add to product taste (4).

The objective was to develop and validate a robust method for the analysis of selected VP compounds, with a good sample turnaround time and minimal requirements on resources (personnel and instrumentation). Methods for the quantification of volatile compounds in MSS can be divided into four categories depending on their trapping approach: direct injection (5-8), cryogenic trapping (9-12), adsorbent trapping $(13,14)$ and sample bag $(15,16)$. Of these methodologies, adsorbent trapping was chosen as it produces a homogenous sample, requires no modification to the smoking machine and permits analysis "off-line" due to the stability of the adsorbed sample.

\section{EXPERIMENTAL}

\section{Smoking}

Commercially available cigarettes from the United Kingdom (UK) market, with deliveries ranging from 1 to $12 \mathrm{mg}$ 'tar', were conditioned according to International Standard (ISO) 3402 (17) and used without further selection. Twenty cigarettes per sample were smoked on a Borgwaldt RM20 smoking machine in accordance with ISO 4387 (18). The
MSS was separated using a $92 \mathrm{~mm}$ Cambridge filter pad and the VP collected in an opaque Tedlar® bag (SKC Ltd, Dorset, UK). Immediately on completion of smoking, the VP was sampled onto prepacked thermal desorption (TD) tubes (Markes Ltd, Pontyclun, UK) using an Alpha-1 personal air sampler (Shawcity, Faringdon, UK) operating at a flow rate of $100 \mathrm{~mL} / \mathrm{min}$. The TD tubes contained two adsorbent beds in series, Carbotrap ${ }^{\mathrm{TM}}$ and Carboxen ${ }^{\mathrm{TM}}$. Three samples were smoked per product with two analyses from each collection bag, giving a total of six measurements per product.

\section{Calibration}

A mixed calibration standard was prepared to mimic the relative concentrations of the 14 analytes typically found in the MSS of UK products. The concentrations of the working standard are given in Table 1. All chemicals used were supplied by Sigma-Aldrich, were of analytical grade and used as received without further purification. Other standards were prepared by serial dilution in heptane. One microlitre of the standard solution was volatilised in a modified gas chromatograph (GC) injection port at $150{ }^{\circ} \mathrm{C}$ and carried onto a TD tube using a stream of inert gas (19).

\section{Analysis}

The sample was introduced using a Perkin Elmer Automated Thermal Desorber (ATD400) coupled to a Perkin Elmer Autosys XL gas chromatograph with flame ionisation detector (GC-FID). Separation of the components was achieved using a PoraPLOT-Q column $(50 \mathrm{~m} \times 0.32 \mathrm{~mm}$ i.d. $\times 1 \mu \mathrm{m}$ film thickness, Varian-Chrompack) with a flow of Helium at $2 \mathrm{~mL} / \mathrm{min}$. A temperature program of $\mathrm{T}_{\text {int }}$ $90{ }^{\circ} \mathrm{C}, 2 \%$ min to $120{ }^{\circ} \mathrm{C}$ (hold $10 \mathrm{~min}$ ) $4 \%$ min to $220{ }^{\circ} \mathrm{C}$ (hold $10 \mathrm{~min}$ ) was used to optimise separation giving a total run time of $60 \mathrm{~min}$. Typical chromatograms for a standard and a MSS sample are given in Figures 1 and 2, respectively.

\section{Calculation}

The amount of each VP component in the sample was determined using the following equation:

$$
\text { Analyte }(\mu \mathrm{g} / \mathrm{cig})=A_{\mathrm{s}} \times \mathrm{RF} \times N \times c
$$

where $A_{\mathrm{s}}=$ average peak response for the sample, $\mathrm{RF}=$ response factor for standard, $N=$ puff number, $c=$ conversion factor (accounts for puff volume [ $35 \mathrm{~mL}]$, number of cigarettes [20] and amount sampled [200 mL]).

\section{RESULTS}

\section{Validation}

The instrument precision, range, linearity and limit of quantitation (LOQ) of the method were assessed in accordance with International Conference on Harmonisation guidelines (20). Recovery was determined using the method of standard addition by introducing a known amount of standard onto a TD tube containing VP matrix. Peak purity 


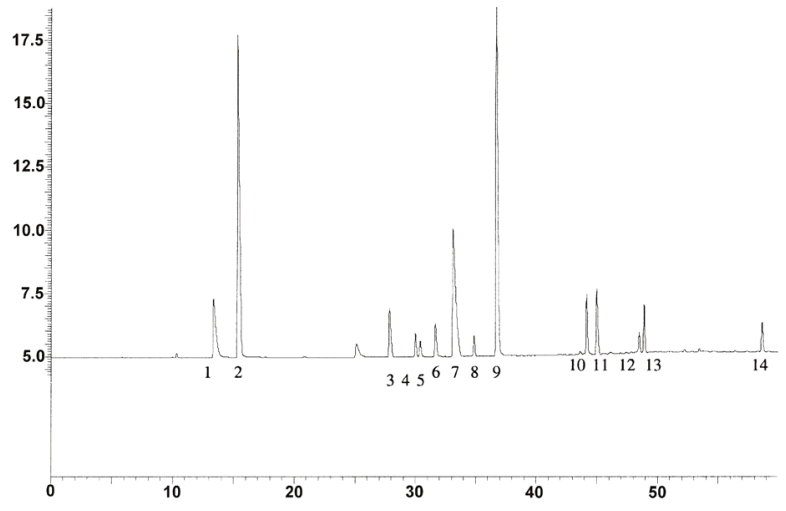

Figure 1. Typical chromatogram of standard injection $(1=$ methanol, $2=$ acetaldehyde, $3=$ acetonitrile, $4=$ acrolein, $5=$ furan, $6=$ propionaldehyde, $7=$ acetone, $8=$ acrylonitrile, $9=$ isoprene, 10 = butyraldehyde, $11=2$-butanone, $12=$ crotonaldehyde, 13 = benzene, 14 = toluene)

was confirmed by mass spectrometry (MS) using a Perkin Elmer Turbomass system in conjunction with the ATD-GC. The validation results are summarised in Table 2 .

\section{Cigarettes}

The concentration of the 14 VP components were measured in nine commercially available brands (A-I) and three reference cigarettes: the CORESTA monitor cigarette (CM3), University of Kentucky reference cigarette 1R4F and our inhouse monitor product (Mon). The configuration details of the cigarettes and the variability of the measurement of the VP components (expressed as coefficients of variation, $\mathrm{CoV}$ ) are given in Tables 3 and 4, respectively. Figures 3 and 4, respectively, illustrate the results obtained for the analysis of carbonyls and volatile organic components in the MSS of the Kentucky 1R4F reference cigarette using this method compared to results from other laboratories.

\section{DISCUSSION}

Methods to measure volatile components of MSS all have their limitations. The use of serial impingers often requires

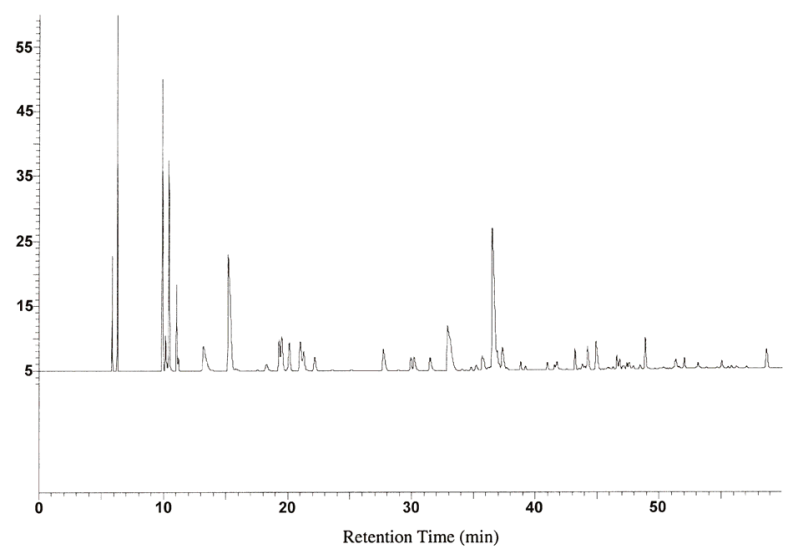

Figure 2. Typical chromatogram of MSS sample

modification of the smoking machine, which can cause difficulties maintaining ISO smoking conditions (10). As the volatile carbonyls are generally trapped separately from other volatile compounds, two separate smoke runs and analyses are required per sample (9). Whilst direct injection can analyse all the VP components using only one instrument, sample turnaround is limited as samples can only be introduced during smoking (5). Due to the limited sample volume that can be introduced into a GC, it is difficult to get a homogenous sample from a cigarette with direct injection. Transfer lines are also required to be kept as short as possible. A gas-sampling valve can be used to obtain an aliquot from the collection bag that will be relatively homogeneous (15). To minimise the ageing of the VP it is imperative that the bag is sampled as soon as possible, hence analysis must occur immediately on completion of the smoking run.

To overcome the problems of homogeneity and turnaround time, the VP can be sampled from the collection bag onto adsorbent tubes. Once adsorbed, all the volatile components remain stable for at least $24 \mathrm{~h}(25-27)$. This allows the smoking to continue while the operator is present, with automated after-hours analysis for improved efficiency. Careful selection of the adsorbents in the TD tube allows complete adsorption of all volatile chemicals of interest. The TD tubes used in this study have two carbon beds. The

Table 2. Summary of method validation results

\begin{tabular}{lccc|c|c}
\hline Compound & Instrument precision $(\% \mathrm{CoV})$ & LOQ $(\mu \mathrm{g} / \mathrm{cig})$ & Range $(\mu \mathrm{g} / \mathrm{cig})$ & Linearity & Mean recovery $(\%)$ \\
\hline Acetaldehyde & 3 & 1.89 & LOQ-1256 & 0.995 & 99 \\
Acetonitrile & 2 & 1.88 & LOQ-1130 & 0.999 & 109 \\
Acetone & 1 & 1.88 & LOQ-1122 & 0.999 & 103 \\
Acrolein & 2 & 2.00 & LOQ-1198 & 0.998 & 111 \\
Acrylonitrile & 2 & 1.92 & LOQ-1152 & 0.998 & 114 \\
Benzene & 2 & 2.08 & LOQ-1248 & 0.999 & 109 \\
2-Butanone & 2 & 1.92 & LOQ-1150 & 0.999 & 111 \\
Butyraldehyde & 3 & 1.91 & LOQ-1142 & 0.999 & 107 \\
Crotonaldehyde & 3 & 2.01 & LOQ-1208 & 0.999 & 115 \\
Furan & 2 & 2.23 & LOQ-1338 & 0.997 & 111 \\
Isoprene & 2 & 1.62 & LOQ-972 & 0.998 & 99 \\
Methanol & 2 & 1.88 & LOQ-1130 & 0.998 & 112 \\
Propionaldehyde & 2 & 1.92 & LOQ-1150 & 0.999 & 109 \\
Toluene & 1 & 2.06 & LOQ-1236 & 0.999 & 111
\end{tabular}


Table 3. Details of cigarettes smoked

\begin{tabular}{|c|c|c|c|c|c|c|}
\hline Cigarette & Configuration rod/filter $(\mathrm{mm})^{\mathrm{a}}$ & Filter & Ventilation & 'Tar' (mg/cig) & Nicotine (mg/cig) & Blend style ${ }^{b}$ \\
\hline A & KS (64/20) & $\mathrm{Y}$ & Y & 12 & 1.0 & Am \\
\hline B & KS $(64 / 20)$ & $\mathrm{Y}$ & Y & 11 & 0.9 & V \\
\hline $\mathrm{C}$ & KS $(64 / 20)$ & $\mathrm{Y}$ & Y & 5 & 0.5 & V \\
\hline $\mathrm{D}$ & KS $(64 / 20)$ & $\mathrm{Y}$ & $\mathrm{N}$ & 12 & 0.8 & V \\
\hline$E$ & KS (59/25) & Y & Y & 1 & 0.1 & V \\
\hline $\mathrm{F}$ & LL (74/25) & $\mathrm{Y}$ & Y & 10 & 0.9 & V \\
\hline G & LL (74/25) & $\mathrm{Y}$ & Y & 8 & 0.7 & V \\
\hline $\mathrm{H}$ & LL Slim (72/27) & $\mathrm{Y}$ & Y & 5 & 0.5 & V \\
\hline 1 & Untipped (59) & $\mathrm{N}$ & $\mathrm{N} / \mathrm{A}$ & 12 & 1.0 & V \\
\hline Monitor & $\mathrm{KS}(64 / 20)$ & $\mathrm{Y}$ & Y & 11 & 0.9 & V \\
\hline CM3 & KS $(64 / 20)$ & $\mathrm{Y}$ & $\mathrm{N}$ & 15 & 1.5 & V \\
\hline 1R4F & KS (57/27) & $\mathrm{Y}$ & Y & 10 & 0.8 & $\mathrm{Am}$ \\
\hline
\end{tabular}

a KS, king size; LL, longer length; Slim, circumference $\approx 20 \mathrm{~mm}$.

b Am, American blend; V, Virginia.

Table 4. Variability of vapour phase measurement (\%CoV)

\begin{tabular}{|c|c|c|c|c|c|c|c|c|c|c|c|c|}
\hline Compound & $A$ & $\mathrm{~B}$ & C & $\mathrm{D}$ & $E$ & $\mathrm{~F}$ & $\mathrm{G}$ & $\mathrm{H}$ & I & Mon & CM3 & 1R4F \\
\hline Acetaldehyde & 5 & 6 & 7 & 5 & 5 & 11 & 10 & 7 & 6 & 12 & 9 & 7 \\
\hline Acetonitrile & 4 & 3 & 6 & 5 & 8 & 7 & 7 & 8 & 8 & 12 & 8 & 7 \\
\hline Acetone & 6 & 3 & 7 & 5 & 4 & 9 & 6 & 8 & 6 & 9 & 7 & 10 \\
\hline Acrolein & 4 & 3 & 5 & 5 & 4 & 9 & 6 & 7 & 5 & 9 & 6 & 6 \\
\hline Acrylonitrile & 5 & 4 & 10 & 11 & 10 & 7 & 8 & 10 & 7 & 10 & 12 & 9 \\
\hline Benzene & 4 & 3 & 6 & 5 & 4 & 9 & 5 & 8 & 5 & 8 & 7 & 5 \\
\hline 2-Butanone & 5 & 3 & 7 & 6 & 5 & 10 & 7 & 7 & 7 & 9 & 6 & 6 \\
\hline Butyraldehyde & 3 & 2 & 10 & 4 & 9 & 10 & 8 & 7 & 7 & 14 & 7 & 6 \\
\hline Crotonaldehyde & 7 & 6 & 8 & 8 & 5 & 11 & 6 & 8 & 11 & 11 & 10 & 13 \\
\hline Furan & 5 & 4 & 9 & 8 & 6 & 9 & 9 & 9 & 10 & 14 & 9 & 8 \\
\hline Isoprene & 5 & 5 & 4 & 11 & 4 & 3 & 8 & 7 & 5 & 8 & 9 & 6 \\
\hline Methanol & 9 & 7 & 9 & 5 & 5 & 9 & 11 & 7 & 10 & 12 & 8 & 11 \\
\hline Propionaldehyde & 6 & 8 & 7 & 8 & 4 & 11 & 11 & 10 & 6 & 12 & 9 & 6 \\
\hline Toluene & 8 & 6 & 12 & 8 & 11 & 9 & 7 & 8 & 10 & 9 & 10 & 10 \\
\hline
\end{tabular}

first carbon bed traps compounds in the boiling range $n-\mathrm{C}_{5}$ to $n-\mathrm{C}_{14}$ whilst the second bed, a carbonised molecular sieve, traps those with a boiling point $<80{ }^{\circ} \mathrm{C}$.

Initial experiments were performed to optimise bed density, particle size and sampling air-flow as well as the choice of adsorbent to ensure that all the required volatile species were adequately trapped and retained by the adsorbents. Further work on aged samples was undertaken to confirm the stability of the adsorbed species over the duration of entrapment, i.e. the maximum time between sampling and analysis. There was no loss of volatiles from the sealed TD tubes for a period of up to $48 \mathrm{~h}$ however, it is recommended that all analysis be carried out within $24 \mathrm{~h}$ of sampling. Loss of sample after this period can be further prevented by the use of Swagelok ${ }^{\mathrm{TM}}$ type end-caps, which have demonstrated no loss of a range of compounds for a period of 21 days at room temperature (27). These compounds covered a wide range of volatility from freon 12 to hexachlorobutadiene on mixed adsorbent bed TD tubes similar in composition to those used in the present study. Further gasphase reactions of trapped species are largely prevented as the individual molecules are kept apart as they are retained in separate pores within the adsorbents (26).
Matching an unknown peaks retention time with known standards does not provide sufficient evidence of a peaks identity or purity. To clarify this MS can be used either in parallel or as an alternate detector to the FID. Using the above matrix of products we found sufficient peak purity to rely upon the peak area counts derived from the FID for calculations. However, is it recommended that peak purity be checked for each sample type using GC-MS. The choice of FID for this work was based largely upon its widespread availability in laboratories throughout the world and its robustness. Appendix 1 details suitable MS conditions and ions for detection of the VP components listed.

The short-term variability of this method is given by the $\mathrm{CoV}$ of replicate samples of the 9 products over a short period of time (typically over one day). From Table 4 it can be seen that the $\mathrm{CoV}$ was $\leq 12 \%$ for all these products regardless of configuration, delivery or ventilation level. The longer-term variability of the method was established over a three-month period for three products, namely CM3, 1R4F and an in-house monitor product. Table 4 shows the longer-term variability was $\leq 14 \%$ indicating consistency of the method under normal operating conditions. 


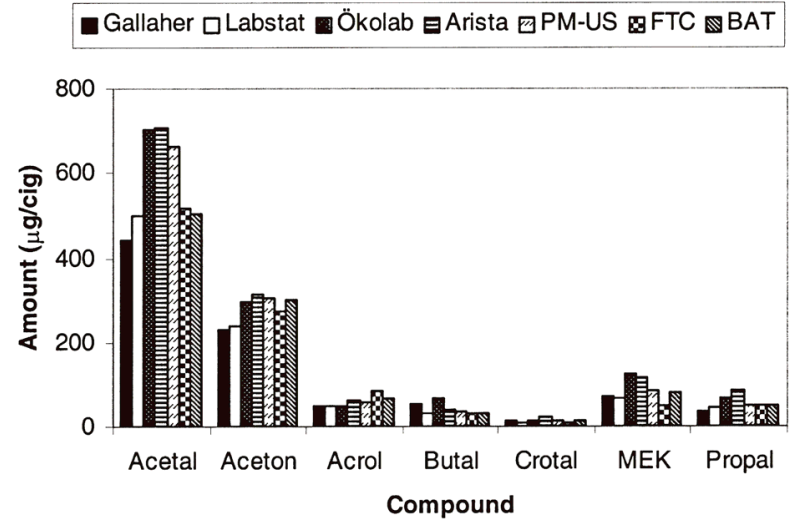

Figure 3. Comparison of $1 \mathrm{R} 4 \mathrm{~F}$ carbonyl compounds data (References: Labstat (21), Arista (22), PM-US (23), BAT (24). Personal communication from Ökolab \& Filtrona Technology Centre (FTC)).

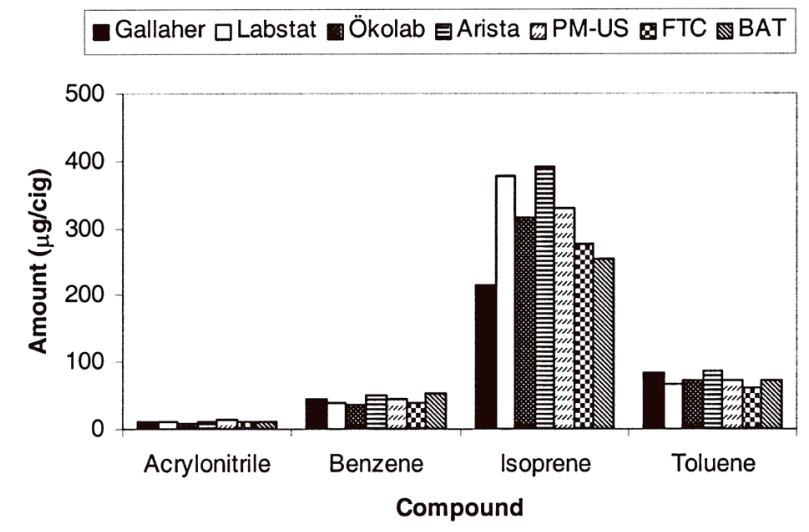

Figure 4. Comparison of $1 \mathrm{R} 4 \mathrm{~F}$ volatile organic compound data. (References: Labstat (21), Arista (22), PM-US (23), BAT (24). Personal communication from Ökolab \& Filtrona Technology Centre (FTC)).

As can be seen from Figures 3 and 4, the VP data for the Kentucky 1R4F reference cigarette obtained by this method are in general agreement with results from six independent laboratories using alternate methodologies. Unfortunately, there was no data available for the comparison of acetonitrile, furan and methanol results.

Although there is no internationally agreed methodology for the determination of vapour-phase chemicals in MSS, there appears to be some consistency between the laboratories detailed above. To trap the carbonyls from MSS, most of the laboratories use a solution of 2,4-dinitrophenylhydrazine (DNPH) and analyse the resultant derivatives by high performance liquid chromatography (HPLC) using ultraviolet (UV) detection. A separate smoking is required for the volatile organic compounds (VOCs) as they are trapped using chilled liquid impingers and analysed by GCMS, normally using selected ion monitoring (SIM). The laboratories do, however, differ in the type of smoking machine (linear or rotary) used, the number of cigarettes ( 5 , 10 or 20) per determination and the number and volume of the liquid impingers.

Despite the similarities of the methodologies used, the results obtained for the 1R4F cigarette differ between laboratories, however, these differences are within the inter-laboratory variability expected for the measurement of "Hoffmann"-type analytes in MSS (28). Furthermore, the results obtained from this study using a unique methodology are consistent with the other results presented for the $1 \mathrm{R} 4 \mathrm{~F}$ given the inter-laboratory variability shown above.

\section{CONCLUSION}

Thermal desorption-gas chromatography with flame ionisation detection (TD-GC-FID) provides a simple and consistent method for the quantification of VP compounds in MSS from cigarettes of different configurations. A run time of 60 min provides information on eleven of the volatile chemicals currently required by the British Columbia regulations using only one analytical instrument. Smoking is also carried out under ISO conditions with no modifications to the smoking machine and minimal preparation of materials. The method can be applied to a wider range of volatile chemicals by careful selection of the adsorbent materials.

\section{REFERENCES}

1. Green, C.R. and A. Rodgman: The Tobacco Science Research Conference: A half century forum for advances in analytical methodology of tobacco and its products; Rec. Adv. Tob. Sci. 22 (1996) 131-304.

2. ISO 3308: Routine analytical smoking machine - Part 1: Definitions and standard conditions; International Organisation for Standardisation, Geneva, 2000.

3. EH40 Occupational Exposure Limits: Health and Safety Books, HSE, Suffolk, UK, 2002, pp. 34-38.

4. Rose, J.E. and F. Behm: Refined cigarette smoke as a method for reducing nicotine intake; Pharmacol. Biochem. Behav. 28 (1987) 305-310.

5. Brunnemann, K.D., M.R. Kagan, J.E. Cox, and D. Hoffmann: Analysis of 1,3-butadiene and other selected gas-phase components in cigarette mainstream and sidestream smoke by gas chromatography-mass selective detection; Carcinogenesis 11 (1990) 1863-1868.

6. Izawa, K., H. Takahashi, T. Sasi, and Y. Sone: New instrument for rapid analysis of tobacco smoke; 45th Tobacco Chemists' Research Conference, Program Booklet and Abstracts, Vol. 45, 1991, p. 38.

7. Laurene, A.H., L.A. Lyerly, and G.W. Young: Direct vapour chromatographic determination of acetaldehyde, acrolein and acetone in cigarette smoke; Tob. Sci. 8 (1997) 150-153.

8. Deutsch, L.J. and A.L Jeffords: An improved method for the analysis of the vapor phase of cigarette smoke; 52nd Tobacco Scientists' Research Conference, Program Booklet and Abstracts, Vol. 52, 1998, pp. 289-295.

9. Health Canada: Determination of 1,3-butadiene, isoprene, acrylonitrile, benzene and toluene in mainstream tobacco smoke; Health Canada Official Method T-116, 1999.

10. Darral, K.G., J.A. Figgins, R.D. Brown, and G.F. Phillips: Determination of benzene and associated volatile compounds in mainstream cigarette smoke; Analyst 123 (1998) 1095-1101.

11. Byrd, G.D., K.W. Fowler, R.D. Hicks, M.E. Lovette, 
and M.F. Borgerding: Isotope dilution gas chromatography-mass spectrometry in the determination of benzene, toluene, styrene and acrylonitrile in mainstream cigarette smoke; J. Chromatogr. 503 (1990) 359-368.

12. White, E.L., A. Sequeria, and C.O. Brooks: Ultrasensitive method for the direct determination of vinyl chloride in fresh mainstream vapour-phase cigarette smoke; 51st Tobacco Scientists' Research Conference, Program Booklet and Abstracts, Vol . 51, 1997, p. 55.

13. Higgins, C.E., W.H. Griest, and G. Olerich: Application of tenax trapping to analysis of gas phase organic compounds in ultra-low tar cigarette smoke; J. Assoc. Anal. Chem. 66 (1983) 1074-1083.

14. Nunez, A.J. and L.F. Gonzalez: Pre-concentration of headspace volatiles for trace organic analysis by gas chromatography; J. Chromatogr. 300 (1984) 127-162.

15. Omori, F., N. Higashi, M. Chida, Y. Sone, and S. Suhara: Internal standard-based analytical method for tobacco vapor phase components; Beitr. Tabakforsch. Int. 18 (1999) 131-146.

16. Sloan C.H., J.S. Lewis, and G.P. Morie: Computerisation of gas-phase analysis of cigarette smoke; Tob. Sci. 21 (1977) 57.

17. ISO 3402: Tobacco and tobacco products: Atmosphere for conditioning and testing; International Organisation for Standardisation, Geneva, 1999.

18. ISO 4387: Cigarettes: Determination of total and nicotine-free dry particulate matter using a routine analytical smoking machine; International Organisation for Standardisation, Geneva, 2000.

19. Method for the determination of hazardous substances. MDHS 72: Volatile organic compounds in air; Health and Safety Executive, HSE, Suffolk, UK, 1992.

20. FDA Federal Register: Validation of analytical procedures: Methodology; Vol 62:96(1997) 27463-27467.

21. Rickert, W.S. and W. Wright: The stability of yields of Canadian mandated analytes from the Kentucy reference cigarette 1R4F; 2002 CORESTA Congress, New Orleans, LA, 22-27 September 2002, Abstract/Program Book, Abstract No. ST26.
22. Reference data for Ky1R4F cigarette; www.aristalabs.com/ ky1r4f.htm; Website accessed 2004.

23. Rustemeier, K., R. Stabbert, H.-J. Haussmann, E. Römer, and E.L. Carmines: Evaluation of the potential effects of ingredients added to cigarettes, Part 2: Chemical composition of mainstream smoke; Food Chem. Toxicol. 40 (2002) 93-104.

24. Baker, R.R., J.R. Pereira da Silva, and G. Smith: The effect of tobacco ingredients on smoke chemistry. Part 1: Flavourings and additives; Food Chem. Toxicol. 42 (2004) 3-37.

25. Advice on sorbent selection and conditioning sample tubes; Markes International Technical Support No.5.

26. Peters, R.J.B and H.A. Bakkeren: Sorbents in sampling. Stability and breakthrough measurements; Analyst 119 (1994) 71-74.

27. Wright, M.D., N.T. Plant, R.H. Brown, and I. de Graffe: Storage stability of TO-14 compounds on single and multi-bed thermal desorption tubes, Measurement of toxic and related air pollutants; Air \& Waste Management Association Conference Proceedings, Vol. 1 (1998) 550-556.

28. Purkis, S.W., C.A. Hill, and I.A. Bailey: Current reliability of measurements of smoke analytes; Beitr. Tabakforsch. Int. 20 (2003) 314-324.

\section{Corresponding author:}

David W.J. McLaughlin

Gallaher Ltd

Galgorm Road, Ballymena, Co. Antrim, BT42 $1 \mathrm{HS}$

$N$. Ireland

Fax +44-28-2566-5152

E-mail: david.mclaughlin@gallaherltd.com

Appendix. Suitable gas chromatography-mass spectrometry conditions and ions for detection of the vapour phase components Table A1. Target and qualifier ions for mass spectrometry detection

\begin{tabular}{lcc}
\hline Compound & Target & Qualifier \\
\hline Acetaldehyde & 29 & 43 \\
Acetonitrile & 41 & 40 \\
Acetone & 43 & 58 \\
Acrolein & 56 & 55 \\
Acrylonitrile & 53 & 52 \\
Benzene & 78 & 52 \\
2-Butanone & 43 & 72 \\
Butyraldehyde & 43 & 72 \\
Crotonaldehyde & 41 & 70 \\
Furan & 39 & 68 \\
Isoprene & 68 & 53 \\
Methanol & 31 & 29 \\
Propionaldehyde & 58 & 57 \\
Toluene & 91 & 92 \\
\hline
\end{tabular}

Perkin-Elmer TurboMass: transfer line $220^{\circ} \mathrm{C}$; ion source $200{ }^{\circ} \mathrm{C}$, electron energy $70 \mathrm{eV}$, emission current $150 \mu \mathrm{A}$. 